\title{
ENTRE A CASA E O MUSEU: ITINERÁRIOS DA PRODUÇÃO DA CRENÇA NO ACERVO DE CORA CORALINA
}

\author{
Clovis Carvalho Britto ${ }^{*}$
}

\section{RESUMO:}

$O$ artigo analisa as estratégias de produção da crença em Cora Coralina a partir da manipulação de seu legado documental destacando como a escritora, herdeiros legais e simbólicos promoveram agenciamentos em prol de sua distinção nas tramas da economia simbólica. Analisando a construção do museu, as publicações e os eventos sustentados no acervo da escritora, observamos como o conjunto de documentos adquiriu centralidade na batalha das memórias que institui personalidades significativas no campo do patrimônio cultural brasileiro.

\section{PALAVRAS-CHAVES:}

Cora Coralina. Acervo. Museu. Patrimônio.

\begin{abstract}
:
The article discusses the production strategies of belief in Cora Coralina and manipulation of its collection by the writter, legal heirs and symbolics promoted on behalf of his distinction in the context of the symbolic economy. Analyzing the construction of the museum, publications and events supported in the collection of the writter, observed as a set of documents acquired centrality in the battle of memories establishing significant personalities in the field of Brazilian cultural heritage.
\end{abstract}

\section{KEY-WORDS:}

Cora Coralina. Collection. Museum. Heritage.

\section{Fronteiras}

I * Realiza estágio pós-doutoral em Estudos Culturais no Programa Avançado de Cultura Contemporânea da Universidade Federal do Rio de Janeiro (UFRJ). Doutor em Sociologia pela Universidade de Brasília (UNB). Professor do Núcleo de Museologia da Universidade Federal do Sergipe (UFS). E-mail: clovisbritto5@hotmail.com. 
Discutir sobre as estratégias de produção da crença em Cora Coralina (I889-1985) a partir da manipulação de seu legado documental destacando como a escritora, herdeiros legais e simbólicos promoveram/promovem agenciamentos em prol de sua distinção na trama da economia simbólica é o objetivo deste trabalho. Ao promovermos uma espécie de arqueologia/genealogia da construção do museu, das publicações e eventos sustentados no acervo da escritora visualizamos como o conjunto documental adquiriu centralidade na "batalha das memórias" que institui personalidades significativas no campo do patrimônio cultural e museus-casa brasileiros. Delgado (2005) definiu esse processo como a construção de Cora como uma Mulher-Monumento em que a disputa pela fabricação de sua biografia envolve uma rede de memórias que ora se apóiam ou se cruzam, ora se excluem no processo de monumentalização da poetisa como símbolo emblemático da cidade de Goiás constituindo, assim, uma peça estratégica na construção desse "lugar da memória".

Nesse sentido, Cora se torna metáfora e metonímia da cidade de Goiás. Talvez por sua memória poética ser incrustada, fossilizada no espaço da cidade de Goiás, lugar em que elegeu dois principais espaços memoriais: os becos e a Casa Velha da Ponte. Dois espaços relacionais por excelência, espaços de redefinição de fronteiras: tornando-se baliza, espaço de separação e costura, fronteira física e simbólica, pontes, conectores.

Poderíamos aproximar da interpretação de Pratt (1999) quando concebe fronteiras como "zonas de contato" entre diferentes povos e culturas, constituindo, ao mesmo tempo, um limite para os portadores de culturas específicas e múltiplas possibilidades de transformação dos agentes do lugar, a partir da colaboração e dos antagonismos. Questão que se complexifica quando consideramos esse espaço não apenas fronteiriço, mas diluidor de fronteiras. Uma espécie de soleira que adquiriu centralidade, moldura que se tornou obra, segundo códigos de sociabilidade impactados pelo trânsito e pela permanência. Daí pensar os becos de Goiás, como espaços de agenciamento, espaços rizomáticos. Um rizoma possui formas diversas, conecta um ponto qualquer com outro ponto qualquer e seus traços não remetem obrigatoriamente a traços de mesma natureza, colocando em jogo regimes de signos muito diferentes. Um rizoma é aliança, é um entre, "não começa nem conclui, ele se encontra sempre no meio, entre as coisas, inter-ser, intermezzo" (DELEUZE; GUATTARI, I995, p. 37). Espaço rizomático ou um espaço liminar, nos moldes como configurou o antropólogo Roberto DaMatta (2000), visualizando espaços dessa natureza como importantes na configuração das sociabilidades:

Como, então, tomar o limem e o paradoxal como negativos em sistemas relacionais, como o Brasil, uma sociedade feita de espaços múltiplos, na qual uma verdadeira institucionalização do intermediário como um modo fundamental e ainda incompreendido de sociabilidade é um fato social corriqueiro? Como ter horror ao intermediário e ao misturado, se pontos críticos de nossa sociabilidade são constituídos por tipos liminares como o mulato, o cafuzo e o mameluco (no nosso sistema de classificação racial); o despachante (no sistema burocrático); a(o) amante (no sistema amoroso); o(a) santo(a), o orixá, o 'espírito' e o purgatório (no sistema religioso); a reza, o pedido, a cantada, a música popular, a serenata (no sistema de mediação que permeia o cotidiano); a varanda, o quintal, a praça, o adro e a praia (no sistema espacial); o 'jeitinho', o 'sabe com quem está falando?' e o 'pistolão' (nos modos de lidar com o conflito engendrado pelo encontro de leis impessoais com o prestígio 
e o poder pessoal); a feijoada, a peixada e o cozido, comidas rigorosamente intermediárias (entre o sólido e o líquido) no sistema culinário; a bolina e a 'sacanagem' (no sistema sexual) (DAMATTA, 2000, p. I4).

Não somente os becos imprimem força na lírica coraliniana.A Casa Velha da Ponte também assume centralidade neste projeto confessional. Também se torna metáfora e metonímia da cidade de Goiás, dos costumes e ethos dos agentes de sua comunidade, fronteira entre memórias individuais e coletivas. A casa, espaço por excelência do feminino, também retoma o lugar da mulher nessa sociedade na transição dos séculos $X I X$ e $X X$, que a máscara lírica Aninha viu ou ouviu dizer e que a máscara Cora Coralina registrou, nesses dois espaços de permissividade poética. Descreve, por exemplo, a forma com que a arquitetura da cidade refletia a clausura destinada às mulheres com seus muros e portões e, principalmente, com as janelas de tabuleta:

Antigamente, as boas casas de Goiás tinham janelas de rótulas como tiveram todas as cidades coloniais deste imenso Brasil. Em Goiás sobreviveram por mais de dois séculos, sobrevivem ainda com velhos costumes domésticos que vão se diluindo através das gerações, ao tempo que as rotulasse modificam sem desaparecer de todo. [...] Foram elas o documentário mais expressivo da segregação da fêmea dentro da casa senhorial.As de Goiás eram chamadas rótulas de tabuleta, de tabuinhas, de colocação horizontal, grampeadas num pino, vertical, móvel, com trincos e tramelinhas laterais, para abrir e fechar à vontade.As paredes onde se encaixavam essas janelas eram de notável espessura, como inda se vê em tantas casas. Comportavam internamente, dos lados, assentos lisos ou com almofadas onde as mulheres, mais comodamente, pudessem estar à rótula. Movendo trincos, pinos e tramelinhas era que a gente da casa via o pequeno mundo da cidade e tomava conhecimento de seus moradores (CORALINA, 2006, p. 85-86).

Cora Coralina, ao descrever a mulher goiana no universo da casa, se aproxima da compreensão do pesquisador e a mulher, dessa forma, assumiria o aspecto relacional ao interagir com a rua através das tabuletas:"viam sem ser vistas","a gente da casa via o pequeno mundo da cidade [a rua]". Desse modo, em alguns momentos as separações entre a casa e a rua, o público e o privado, o individual e o coletivo tornam-se tênues. Isso se evidência nas janelas de rótulas, mas também no alinhamento das casas que, cochicham umas com as outras, muitas vezes não possuindo calçadas e estabelecendo rituais e sociabilidades, a exemplo dos códigos que informam se o morador está ou não apto a receber visitas, ou se encontra na residência a partir da abertura das portas do meio e da rua. A constatação realizada a partir da análise do texto poético também é evidenciada por DaMatta, quando, em A casa e a rua (1997), afirma que a mulher tornou-se ente mediador por excelência. São mediatrizes e meretrizes (mediadoras), ligando o interno ao externo. Ao ousar sair do espaço tradicionalmente destinado à mulher, tornando-se através da escrita protagonista/enunciadora de seus desejos e porta-voz dos outros, a própria Cora se torna baliza, limite, fronteira.A propósito, podemos dizer que existe uma Goiás antes e uma depois de Cora Coralina.

Se a arquitetura de Goiás, o papel da mulher na sociedade e a própria opção estética da lírica coraliniana ao privilegiar a casa e os becos assumem esse lugar de intermezzo, tal proposta assume contornos mais fortes quando nos deparamos com a configuração do Museu-Casa de Cora Coralina ou, a priori, com a configuração de um Museu-Casa ou Casa-Museu. Para além das diferentes tipologias de Museus-Casas levando em conta informações históricas, artís- 
ticas, arquitetônicas e sociais (de personalidades, de colecionadores, de beleza, de eventos históricos, da sociedade local, ancestrais etc.), o que nos interessa é perceber nestes museus que o documento/monumento é a simbiótica relação entre o edifício, a coleção e o proprietário - anfitrião do espaço (PUIG, 20l I). Aqui, torna-se importante a afirmação de Rangel (2007, p. 83) quando destaca a preocupação de que o Museu-Casa não fique engessado pelo conceito:"não somos mais uma casa, nem 'somente um museu'; somos o somatório destes dois universos ricos em possibilidades de atuação".Vislumbramos, assim, um trânsito entre as dimensões pública e privada ao concebermos a própria casa como uma peça fundamental do museu.

Questão que se conplexifica quando observamos, muitas vezes, que o Museu-Casa e as demais estratégias de produção da crença contribuem para que o indivíduo homenageado esteja mais vivo post mortem do que quando ele estava entre nós. Nesse sentido, buscamos compreender as relações entre acervos literários e economia simbólica considerando as estratégias de manipulação da memória dos titulares e os lucros simbólicos e materiais decorrentes dessa manipulação. Tarefa empreendida em vida pelos integrantes do campo de produção simbólico em busca do estabelecimento de legitimidades manifestas nas formas de prestígio, autoridade e distinção (BOURDIEU, 1983).As lutas pela distinção são constantes e torna-se necessário um contínuo processo de reavaliação, reinvenção e reverberação da memória literária dos agentes a quem se pretende "imortalizar”. Na verdade, os acervos literários possuem valor estratégico nesse processo, já que consistem em indícios e manifestação material de determinados aspectos da trajetória e das obras que interessam consagrar. Surgem, assim, mecanismos que conferem legitimidade (e ilegitimidade) a ações empreendidas em nome da prevalência de determinadas leituras sobre o passado (versões concorrentes) e do monopólio do direito de falar sobre o passado (capitais diferenciados).

É por essa razão que seguimos a opção de Heymann (2004) ao visualizarmos como os acervos interferem na construção de legados. Não apenas como herança material e política deixada às gerações futuras, mas entendidos como investimento social em virtude do qual uma determinada memória individual é transformada em exemplar ou fundadora de um projeto, ou, em outras palavras, ao trabalho social de produção da memória resultante da ação de "herdeiros" ou "guardiães":"a produção de um legado implica na atualização constante do conteúdo que lhe é atribuído, bem como na afirmação da importância de sua rememoração" (HEYMANN, 2004, p. 3). Os agentes interessados se utilizam dos acervos como instrumentos úteis para a criação, manutenção e divulgação da memória do personagem, fomentando a criação de espaços de evocação da imagem e de atualização da trajetória do titular por meio de trabalhos acadêmicos, reedições, exposições, eventos e comemorações. Não desconsideramos as estratégias que o próprio titular forjou com vistas à criação de uma memória que sobrevivesse a sua morte, das quais a constituição do acervo pessoal seria um ilustrativo exemplo. Mas o que nos interessa é perceber as apropriações posteriores dessa memória e as formas de encenação da "imortalidade" instituídas pelos agentes e instituições que se revestem da condição de "herdeiros" ou "guardiães" dessa memória.

A produção do legado se estabelece conjuntamente com a produção da crença nesse legado. Para além da existência de uma trajetória e de um projeto criador considerado excepcional, torna-se necessário que a energia social produzida em torno de um nome próprio se estenda ao longo do tempo. Quanto maior a extensão cronológica do prestígio, maior é a eficácia dos mecanismos materiais e simbólicos mobilizados contra a ameaça do esquecimento. Desse 
modo, não basta ser um escritor conhecido e reconhecido em sua geração, é necessário reunir subsídios para que sua obra conquiste perenidade ou reconquiste o prestígio perdido ou não obtido em outros tempos. Tarefas empreendidas não apenas pelos herdeiros legais e simbólicos do autor, mas pelo conjunto de agentes que integram o espaço de possíveis expressivos de produção simbólica: escritores, editores, críticos literários, biógrafos, jornalistas, instituições de ensino e cultura, dentre outros. Aqui é importante compreendermos as ações empreendidas pelo artista (e post mortem pelos demais agentes) para a gestão e manutenção do capital de legitimidade acumulado.Ações que convergem para o estabelecimento de uma "marca" distintiva, identificada com o capital simbolizado por seu nome e renome e, conseqüentemente, com a posição ocupada no campo artístico. O escritor fornece eficácia à alquimia simbólica, na medida em que garante a produção de um bem dotado de uma "marca" específica. É por isso que no campo artístico os "descendentes legítimos" (familiares, colaboradores, discípulos) lutam para a perpetuação da "mensagem", mas não para substituir o "criador", ou seja, se unem para a perpetuação do carisma.

Nesse aspecto a escolha de Cora Coralina não foi aleatória, nos amparamos nas orientações de Chagas (2008) quando, a partir da noção de uma poética do espaço, refletiu sobre as experiências de casas-museus a exemplo do Museu Casa de Cora Coralina. Enquadrando Cora como uma heroína popular, a partir da dimensão épica de sua trajetória, concluiu que o mundo museal brasileiro está em transformação ao se abrir para a valorização de vozes não dominantes e historicamente silenciadas. Para tanto, apresenta algumas interrogações que nos servem como pontos de partida:

Afinal de contas, porque essa casa - e exatamente essa casa - foi transformada em uma casa museu? Por que essa casa deixou de servir como habitação de pessoas, foi ressignificada, e passou a ser um espaço explicitamente poético e político? Por que a vontade de memória, a vontade de patrimônio e a vontade de museu se concentraram nessa casa - e exatamente nessa casa - transformando-a num espaço de teatralização do passado e de criação de memórias do futuro? (CHAGAS, 2008, p. 2).

\section{A anfitriã}

Cora Coralina desenvolveu uma trajetória de vida e um projeto criador sui generis culminando com sua volta a casa familiar em Goiás 45 anos depois, lugar em que escreveu sua obra e construiu seu acervo literário. $\mathrm{Na}$ casa ancorada às margens do Rio Vermelho reuniu centenas de "papéis de circunstância" que ficaram amontoados em gavetas e caixas enquanto rascunhava novas obras e aguardava a publicação das mesmas. No final de sua vida, período de uma explosão discursiva em torno de seu nome e imagem, apesar de receber alguns prêmios de projeção nacional como o de Doutora Honoris Causa (1983) pela Universidade Federal de Goiás, o Juca Pato (1984) da Folha de São Paulo e União Brasileira dos Escritores e o Grande Prêmio da Crítica (1984) da Associação Paulista de Críticos de Arte e das crônicas de Carlos Drummond de Andrade que chancelaram nacionalmente sua obra, Cora ainda encontrou dificuldades para publicar seus livros. Conforme descreveu no poema "Meu vintém perdido”, de Poemas dos becos de Goiás e estórias mais (1965), permaneceu treze anos no esquecimento "esperando se fazer a geração adolescente/ que só o conheceu na sua segunda edição" (CORALINA, 2007, p. 52). E em entrevistas, diários e correspondências não é incomum encontrá-la falando sobre essa te- 
mática desde 1960 quando desenvolveu uma peregrinação pelas editoras paulistas em busca da publicação de seu primeiro livro (BRITTO; SEDA, 2009). Frase que inaugura o texto de abertura escrito para a segunda edição de Poemas dos becos: "mais fácil, para mim, escrever um livro do que publicá-lo. Devo a tantos chegar a esta edição.Amigos, muitos, me estenderam as mãos, cuidaram da nova apresentação, escoimaram erros numa revisão minuciosa, me socorreram nas dificuldades" (CORALINA, 200I, p. 21). Em carta datada de 1965, ao escritor Augusto Lins, a poetisa expôs a dificuldade:"muito me ajudaria perante as editoras, para a publicação de um livro de contos, se tudo quanto sentiu lendo esses Poemas e externou com magia na sua carta, fosse publicado em revista ou jornal dessa culta cidade e assinado com a grandeza de seu nome". Destacando, ainda, que o destinatário possuía um nome "altamente credenciado" e que, por isso mesmo, a crítica depois de publicada deveria ser enviada para a Editora José Olympio: "a edição dos Poemas já está esgotada. Sinto necessidade de apoio para novos lançamentos. Acontece o seguinte: embora me ajude o conteúdo dos livros, desajuda-me, contudo, a idade e... estamos no Brasil".

Isso é evidente se observamos que embora seu nome fosse conhecido nacionalmente e tivesse muitos livros prontos, quando faleceu havia publicado apenas três livros de poemas com as seguintes reedições: Poemas dos becos de Goiás e estórias mais publicado em 1965 pela Editora José Olympio e sua segunda e terceira edições pela Editora da Universidade Federal de Goiás, respectivamente em 1978 e 1980; Meu livro de cordel publicado pela Livraria e Editora Cultura Goiana em 1976; e Vintém de cobre pela Editora da Universidade Federal de Goiás em 1983, com segunda edição pela mesma editora um ano depois. A análise das reedições dos livros de Cora Coralina revela que foram lançadas justamente no período de sua maior projeção nacional, ou seja, a partir de 1980. Todavia, ao contar com o auxílio de amigos para editar suas obras e, nesse sentido, concordar que seus livros fossem publicados por editoras goianas, contribuiu para que seu nome e imagem fossem conhecidos mais do que seus livros. No acervo da escritora é possível identificar matérias em jornais de Goiânia cujos redatores reclamavam da ausência dos livros de Cora nas livrarias goianas e de outros estados. Essa repercussão contribuiu para que a Editora da Universidade Federal de Goiás lhe escrevesse prometendo-lhe uma solução para o impasse:

Prezada amiga Cora. Só agora respondo a sua carta, depois de ter acertado algumas providências a respeito de seu livro. Embora a sua poesia dispense qualquer promoção, é evidente que a crônica de Carlos Drummond de Andrade veio tornar mais fácil o nosso trabalho de difusão e venda do seu livro fora de Goiás. Infelizmente esta Editora estava presa por um contrato de exclusividade com a Livraria Planalto e somente ela, como distribuidora exclusiva, poderia e deveria remeter os livros publicados pela Universidade para as principais livrarias do País, tarefa da qual não estava se desincumbindo a contento. Entramos em entendimento com a Livraria Planalto e, graças à compreensão e boa vontade do Sr. Sebastião de Miranda, podemos agora utilizar os serviços de outras firmas fora do Estado de Goiás. Já nos dirigimos a três das melhores distribuidoras de livros do País visando, especialmente, à colocação do seu livro nas cidades do Rio de Janeiro, São Paulo e Belo Horizonte. Junto segue cópia da carta endereçada a essas Distribuidoras para seu conhecimento. Os 1.000 exemplares de sua propriedade estão guardados na Imprensa da UFG onde poderão ser apanhados quando assim o desejar. Cordial abraço deste seu amigo e admirador (REZENDE, I98I). 
Escolhemos este documento por acreditarmos ser ilustrativo das relações que o nome ou marca "Cora Coralina" empreendia no campo literário brasileiro após a crônica e as cartas de Carlos Drummond de Andrade que reconheceram a importância do legado da poetisa goiana. Questão explícita no ofício quando afirma que o poder simbólico da marca "Drummond" facilitaria sobremaneira a difusão da obra da poetisa fora de Goiás. Reconhecimento que acarretou maiores olhares sobre a escritora que, por conseguinte, despertaram o interesse da crítica e do público leitor e exigiram que sua editora modificasse o plano de ação visando uma distribuição eficiente dos livros para fora do estado. Além dessa "radiografia" de um momento do campo literário, destaca que os mil exemplares destinados à autora já estavam a sua disposição. Muitas editoras dispõem em contrato a possibilidade dos autores receberem seus direitos autorais em dinheiro ou em exemplares. No caso de Cora Coralina, ela optava por receber sua parcela em livros que eram vendidos em sua própria residência para as dezenas de turistas de diversas partes do País e do mundo que a procuravam. Desse modo, ao mesmo tempo em que transformava sua casa em uma espécie de livraria, difundia seu nome e reforçava a estratégia de relacionar contornos biográficos a sua obra: o leitor além de conhecer a autor do livro, adquiria a obra na casa em que foi elaborado, no espaço descrito pelo narrador e pelo "próprio" narrador, visto que ali quem vendia e conversava com os leitores não era apenas Ana Lins, mas também a personagem Cora Coralina. $O$ escritor e sua obra, ao vivo e ao mesmo tempo, na Casa Velha da Ponte (um dos espaços mnemônicos eleitos pela escritora e fundamentais para a compreensão de seu projeto criador). Muitas vezes, a escritora fazia questão de declamar seus versos e escrever um poema exclusivo em cada uma das dedicatórias, relacionado ao nome, a profissão ou a algum dos temas trazidos pelo interlocutor. Ação que reforçava a engrenagem do campo literário ao ponto dessa prática ser incorporada no roteiro turístico da cidade de Goiás: conversar com Cora Coralina, comprar seus doces e livros, ouvir a declamação de seus poemas.

Uma visita a Goiás, a antiga capital do Estado, não se completa sem que se vá conhecer Cora Coralina. Ela mesma é quem o diz: Já pertenço ao patrimônio da cidade'. Conhecê-la, porém, não é apenas ir vê-la: 'Você veio aqui conhecer Cora Coralina', diz ela a uma visitante, 'não veio olhá-la na cara não. Conhecê-la é conhecer o seu espírito, é levar consigo, ao sair, o seu íntimo, a sua mensagem de otimismo, de juventude, de poesia'. A sala está sempre cheia: gente sai, gente entra. De tudo quanto é lugar: SP, RJ, DF, GO, são as iniciais que exibem as chapas de carros estacionados por perto. Há os que querem comprar seus doces e livros e os que só desejam ouvi-la dizer seus poemas. E ela vai dizendo a propósito de qualquer coisa de que esteja fazendo (RAMOS, I97I, p. I).

Apesar de dizer em entrevistas não se importar com a imortalidade simbólica e que "o que vale é a imortalidade da carne, dos músculos, dos ossos, da massa cinzenta" (CORALINA, 2004, p. I), observamos que Cora dedicou parte de sua vida à busca da imortalidade por meio de suas obras. Em diversos poemas encontramos esse anseio, a exemplo do poema em epígrafe neste item que reafirma que quando morrer não morrerá de tudo já que estará nas páginas de seus livros. Aqui dialogamos com El Far (2000) ao concebermos tais estratégias autorais como mecanismos de "encenação da imortalidade", garantindo a sobrevivência de determinadas memórias e, por isso mesmo, a invenção de tradições. No caso de Cora Coralina essa "imortalidade" pode ser estendida ao 
seu acervo pessoal que compreende seus objetos pessoais, seu arquivo literário e sua biblioteca. Muitos são os turistas e freqüentadores da casa da poetisa que ainda se lembram de determinados objetos ou que seu acervo documental permanecia espalhado sobre mesas ou empilhados em caixas de papelão esparramadas pela casa. Além de seu conteúdo, a materialidade do acervo pessoal aciona memórias de e sobre Cora Coralina contribuindo para a fabricação de determinados repertórios sobre a personagem e, por isso mesmo, articulando valor econômico e simbólico. A gestão do legado consiste em promover a vida e obra da autora, reatualizando e ritualizando determinadas versões construídas por ela e por outros agentes de acordo com os interesses dos herdeiros, das instituições de guarda e do campo literário vigente. Nesse aspecto, é fundamental vislumbrar a ação do Museu-Casa de Cora Coralina na produção/consolidação da sua memória biográfica (DELGADO, 2005).

\section{A casa e o museu-casa}

Após a morte de Cora Coralina seus herdeiros venderam a casa em que residiu a maior parte da vida, onde elaborou sua obra e constituiu seu acervo documental, para a Associação Casa de Cora Coralina, pessoa jurídica de direito privado e de natureza cultural fundada em 28 de setembro de 1985. Instituição criada com o intuito de "preservar bens móveis e imóveis, assim como dar prosseguimento à concretização dos ideais da poetisa", tendo como finalidades preservar sua memória e divulgar sua obra (ASSOCIAÇÃO CASA DE CORA CORALINA, 1985, p. I-5).

De início, a pergunta a ser feita é qual memória seria "preservada" pela associação. Nessa ordem de idéias, a ata deixa entrever a resposta quando afirma a intenção de "dar prosseguimento à concretização dos ideais" da autora, ou seja, seria a memória selecionada pela titular. Memória essa imbricada em seus "bens móveis e imóveis" e daí a importância de preservar sua casa e seu acervo pessoal. Os filhos da poetisa venderam a Casa Velha da Ponte e os objetos nela presentes para que a Associação criasse um museu biográfico, ação concretizada graças aos recursos da Construtora Alcindo Vieira de Belo Horizonte e da então Fundação Nacional Pró-Memória, atual Instituto do Patrimônio Histórico e Artístico Nacional, que possibilitaram a aquisição dos bens (130 milhões de cruzeiros) e a restauração dos mesmos (59 milhões de cruzeiros).Aqui é oportuno recordar a criação do Museu-Casa de Cora Coralina. Inaugurada em 20 de agosto de 1989 na data em que se comemorou o centenário de nascimento da escritora, a "Casa de Cora", como é comumente chamada, coopera com a paisagem e o endereço na realização de duas tarefas que se aproximam das que Cunha (2003) identificou ao analisar a Casa de Jorge Amado: reinvestir a inscrição da memória e plasmar a narrativa autobiográfica. A Casa de Cora se torna, desse modo, uma construção autobiográfica com forte assinatura e, como um texto, impõe a sua própria narrativa "aberta à leitura, mas resistente às interpretações que a desvirtuem, que rasurem ou alterem a imagem instituída do escritor" (CUNHA, 2003, p. I 25). O Museu se tornou um dos principais espaços de fabricação/consagração do legado coraliniano na medida em que foi montado no espaço biográfico eleito pela autora, lugar que reúne seus objetos pessoais, reconta uma leitura específica da obra e de sua história de vida e que se tornou no principal guardião de seu acervo documental (embora não seja o único).

Amigos e familiares decidiram consolidar e criar mecanismos para a reinvenção da crença em Cora Coralina e ao longo dos anos vêm instituindo uma 
série de eventos destinados à homenageá-la, revisitar sua vida e obra e a analisar o seu legado. Nesse sentido, diversas instituições estiveram envolvidas nessas comemorações abrigando ou produzindo eventos ou criando e fornecendo os discursos a eles relacionados: museus, bibliotecas, exposições, biografias, revistas, livros, praças, nomes de ruas e instituições, programas especiais veiculados na TV, editoras, eventos como o "Dia do Vizinho" e o "Dia do Cozinheiro" (criado pela poetisa e comemorado anualmente no dia de seu aniversário, 20 de agosto), as comemorações do centenário de seu nascimento (em 20 de agosto de 1889), do cinqüentenário de sua volta à cidade de Goiás (em março e abril de 2006) e dos seus 120 anos de nascimento (durante todo o ano de 2009). Conforme analisa Heymann (2004), as datas comemorativas não são dotadas de valor intrínseco, nem se justificam no passado. Seus significados resultam da atribuição de valor ao evento ou pessoa que se recorda, envolta nos imperativos do presente e nos lugares ocupados pelos agentes que comemoram.A importância desses eventos seria construir mecanismos que legitimariam ações em nome da memória (sobre qual leitura do passado e o monopólio do direito de falar sobre o passado), acionando, assim, a rede de economia simbólica em torno de determinadas pessoas e fatos. Nesse aspecto, possuir acervos consiste em uma estratégia importante para adquirir essa legitimidade. Eles embasam exposições, pesquisas, publicações e, ao mesmo tempo, constituem em forma de "atestar" a importância das comemorações:"os acervos documentais e o capital de testemunho de que são investidos ocupam um lugar central, bem como os acervos museológicos e os atributos de autenticidade que conferem às peças sua força simbólica” (HEYMANN, 2004, p. 5). Também é importante destacar que não basta possuir acervos, mas desenvolver estratégias para utilizá-los como trunfos ao subsidiar homenagens, o prestígio das instituições e pessoas deles responsáveis, as redes de relações desses agentes, os contatos nas esferas acadêmica, governamental e junto a agências de financiamento.

No caso de Cora Coralina a importância do acervo como subsidio a legitimação de muitas realizações em seu nome é evidente. Exemplo disso foi a opção dos herdeiros em dividir o acervo oficial da autora, ambos de propriedade da família: um sob a responsabilidade e guarda da Associação Casa de Cora Coralina, localizado no Museu Casa de Cora Coralina em Goiás-GO, e outro sob os cuidados de Vicência Bretas Tahan, filha da autora e representante legal dos herdeiros, localizado no apartamento da mesma na capital paulista. Embora saibamos que os acervos pessoais não são completos e que outros agentes possam ter conjuntos documentais relativos a determinado indivíduo, aqui observamos a configuração de dois acervos oficiais da poetisa resultantes do desmembramento dos documentos acumulados em vida pela titular. Surge um acervo que era privado e se tornou público (no caso do acervo do Museu-Casa de Cora Coralina) e um acervo que permaneceu privado (o acervo sob a guarda da filha de Cora). A família, que é detentora dos direitos autorais da poetisa, optou por deixar no Museu a biblioteca, os recortes de jornais, a correspondência e os originais das obras já editadas, permanecendo com os textos inéditos e outros documentos selecionados antes da venda do imóvel e abertura do museu em agosto de 1989. Separação que propicia a freqüente publicação de obras póstumas (fruto da compilação de inéditos) e de eventos (fruto da utilização do material já editado). Desse modo, tanto a Associação quanto a família possuem discursos de autoridade sobre o legado memorial de Cora Coralina. Discursos na maioria das vezes interdependentes e, embora não exclusivos, percebemos a família se dedicando a gestão editorial e jurídica e a Associação à gestão museológica e de eventos e comemorações em torno da escritora. 
A primeira ação da família foi separar os textos inéditos do restante do material. Já a Associação focou na seleção do acervo documental e do acervo museológico (os documentos que comporiam a exposição do museu e os que ocupariam a reserva técnica). $O$ acervo pessoal da autora foi e vem sendo utilizado pelos herdeiros (legais e simbólicos) com vistas à promoção e à preservação de determinadas leituras sobre sua obra e vida, garantindo sua “imortalidade' e suscitando um renovado interesse do público no mercado de bens simbólicos. Para tanto, inicialmente analisaremos a gestão editorial promovida pela família em parceria com a Editora Global, a gestão memorial/ museológica realizada pela Associação Casa de Cora Coralina e a vigilância comemorativa empreendida tanto pela família quanto pelos membros da Associação visando, a partir do acervo, compreender as estratégias de renovação da crença no nome Cora Coralina.

\section{Acervo no entre-lugar}

Após a morte de Cora e a decisão de vender o imóvel para a criação do museu,Vicência Bretas Tahan, filha caçula da escritora que representa legalmente a família, levou parte do acervo documental para sua residência na capital paulista. Esse conjunto em sua maioria se constituía de textos inéditos visando um projeto de publicação ao longo do tempo: a primeira ação da família, até para facilitar as negociações já que residiam no estado de São Paulo, foi estabelecer no ano da morte da escritora um contrato de edição exclusivo com a Global Editora, sediada na capital paulista. Na verdade, desde 1983 a Global vem empreendendo ações no sentido de reeditar constantemente a obra coraliniana, publicar textos inéditos da autora, além de inseri-los em coleções de poesia e coleções infanto-juvenis. Ainda em vida, Cora autorizou que a editora fosse responsável pela quarta edição de Poemas dos becos de Goiás (1983). De acordo com o histórico descrito no site da editora, fundada em 1973 a Global teve sua produção voltada para livros considerados referência para o pensamento socialista, publicando autores como Marx, Engels e Lênin. Também privilegiou em seu catálogo a publicação "dos mais conceituados autores da literatura em língua portuguesa, consagrados tanto no cenário nacional como internacional", consistindo em uma das maiores exportadoras de autores brasileiros publicados em língua espanhola, atendendo toda a América Latina e os Estados Unidos. Em seu material de divulgação os autores mais citados como integrantes de seu catálogo são Ana Maria Machado, Câmara Cascudo, Cora Coralina, Ferreira Gullar, Florestan Fernandes, Gilberto Freyre, Ignácio de Loyola Brandão, Marina Colasanti, Marcos Rey, Ruth Rocha e Mário Quintana.A estratégia de difundir a idéia de que seu catálogo reúne os mais conceituados escritores de língua portuguesa serve para que cada um dos autores integrantes reforce o capital simbólico do outro, gerando legitimidade e contribuindo para que a editora também receba uma parcela do capital simbólico de seus "parceiros". No caso de Cora Coralina, embora ela também tenha trilhado as veredas da prosa curta e da literatura para crianças, sua visibilidade maior se dá pela poesia. Conforme salienta Moura (2009), ao optar trabalhar com um gênero que conquista pouco espaço no mercado editorial brasileiro, a publicação se torna um duplo prêmio para o autor: entra no rol dos "consagrados" ao ter sua obra editada por uma concorrida editora e, também, consegue fazê-la abrir concessão a um gênero não rentável. Nesse aspecto, o fato de "atentar à produção de poesia converte-se em capital simbólico para a editora, que com isso reforça sua imagem de pouco comprometimento com o mercado" (MOURA, 2009, p. 36I). 
A partir da Editora Global a obra de Cora Coralina começou a ter um melhor esquema de distribuição e, como o problema não era mais o alcance do público leitor, tornava-se necessário desenvolver estratégias de difusão que despertassem o interesse pela leitura de sua obra. De imediato a ação foi publicar a primeira edição de Estórias da casa velha da ponte, livro de contos organizado pela autora e lançado no mesmo ano de sua morte, 1985. A editora apostou não apenas em reeditar os três livros de poemas inserindo novos comentários críticos e uma série de fotografias da autora e de Goiás, mas em lançar facetas pouco conhecidas da escritora, como a Cora cronista e contista e também a autora de livros para crianças. Seguindo essa estratégia publicou Os meninos verdes (1986), A moeda de ouro que um pato engoliu (1987) e $O$ tesouro da casa velha (1989). Este último, organizado pela escritora Dalila Teles Veras e publicado no ano em que se comemorava o centenário de nascimento da escritora. $\mathrm{Na}$ introdução do livro, Dalila justificou a homenagem: "Cora Coralina comemorou 100 anos juntamente com a nossa República, e este livro de contos inéditos, selecionados do espólio deixado por ela, veio para festejar o evento".

Além de publicar os inéditos, a família também decidiu editar o material aos poucos, diluindo a presença de Cora Coralina ao longo do tempo ou, porque não dizer, desenvolvendo mais uma forma de encenar a imortalidade: "Temos centenas de poemas e contos todos ainda guardados na gaveta. Todo o material inédito de minha mãe ficou comigo. Os originais de livros já editados foram para Goiás. Os inéditos aos poucos serão publicados" (SENA, 2002, p. I). Conjuntamente com o livro $O$ tesouro da casa velha a Global publicou a biografia romanceada Cora coragem, Cora poesia (1989) nas comemorações pelo centenário de Cora Coralina. Escrita por Vicência Tahan a obra está incluída no catálogo da editora no rol das "obras de Cora Coralina" e auxilia na fabricação de uma biografia oficial produzida pela representante da família e difundida pela editora. Como mecanismo de celebração a biografia "orienta" as leituras possíveis sobre a vida e obra coraliniana, visto que a autora além de filha é a representante legal da família nas ações de autorizar ou vetar a utilização da imagem e da obra de sua mãe, freqüentemente assediada para adaptações no teatro e no cinema. Baseados no acervo documental e em obras publicadas anteriormente, a editora ainda publicou Villa Boa de Goyaz (200I), O prato azul pombinho (200I), O poema do milho (2006), As cocadas (2007) e A Menina, o cofrinho e a vovó (2009). Além disso, editou o livro Os melhores poemas de Cora Coralina (2004), coletânea de poesias seguida de análise literária, biografia e fortuna crítica organizada pela poetisa e crítica literária Darcy França Denófrio para integrar a Coleção "Os Melhores Poemas". A coleção consiste na seleção de poesias do legado édito de $6 \mathrm{I}$ autores considerados expoentes da literatura brasileira e mundial. A escolha das obras e produtores e dos escritores e críticos convidados para a seleção e prefácios deve obter consenso dentre os detentores de distinção no campo literário. Demonstra Bourdieu (1996b, p. 68) que assim "como os caminhos da dominação, os caminhos da autonomia são complexos, se não impenetráveis. $E$ as lutas no seio do campo [...] podem servir indiretamente aos escritores mais preocupados com sua independência literária”. Dessa forma, a obra de Cora Coralina se legitima na medida em que é inserida na coleção (masculina quase que em totalidade), se respaldando no prestigio dos autores publicados, a exemplo de Castro Alves, Cecília Meireles, João Cabral de Meto Neto, Luis de Camões, Machado de Assis, Manuel Bandeira e Mário de Andrade.

A família de Cora publicou o livro Cora Coralina: doceira e poeta (2009), lançado nas comemorações dos I 20 anos de nascimento da poetisa na abertura da 
exposição comemorativa no Museu da Língua Portuguesa, capital paulista. A obra há mais de uma década era anunciada pelos herdeiros, visto que além de escritora Cora se notabilizou como doceira, ao ponto de dizer ser mais doceira do que intelectual. Publicado pela Editora Global, o livro traz fotografias dos doces, receitas tradicionais e fotos da cidade de Goiás. Além disso, apresenta fotografias e textos inéditos da autora relacionados à culinária e pela primeira vez os textos de um caderno de receitas pertencentes à Cora Coralina, conforme relatou Vicência Tahan:

Este caderno eu sempre tive. É um caderno de receitas que minha mãe fazia em casa. E este livro eu estava preparando junto a editora há dois anos. Só as receitas não davam para preencher o livro. Então, eu separei escritos e cartas dela que falassem sobre doce. Eu fui procurando tudo isso e juntando para o livro. Nisso eu demorei dois anos. Há também as receitas que ela fazia para vender. Em Goiás, ninguém faz doce igual ao da minha mãe. Eles fazem doces cristalizados. Ela fazia doces glacerizados. $O$ caderno estava guardado. Ele é único. Se alguém disser que tem outro, mente (BORGES, 2009, p. 3).

A entrevista de Vicência indica que ela possui vários originais inéditos de sua mãe, ao ponto de permitirem uma seleção de temas relacionados especificamente a doces. Do mesmo modo, reafirma a singularidade dos doces de Cora e a importância do livro baseado no único caderno de receitas de autoria de sua mãe. Ao destacar que só as receitas não davam para preencher o livro deixa implícito a estratégia editorial de recorrer mais uma vez ao acervo pessoal da escritora no intuito de publicar receitas, textos e fotografias, reafirmando a produção da crença na indissociação entre a arte culinária e a literatura, insistentemente afirmada em vida por Coralina. $\mathrm{O}$ acervo, mais uma vez, encena a imortalidade não apenas de Cora, mas de parte do patrimônio imaterial expresso pelos saberes e sabores da culinária goiana. Nesse sentido é explicita a relação entre o acervo documental e economia, não apenas na comercialização do livro no valor de I 19 reais, mas na movimentação de ingredientes para a execução das receitas, na comercialização das mesmas e na mobilização de profissionais e empresas cujos objetos foram utilizados nas fotos e cujos nomes, endereços e telefones de contato se encontram dispostos ao final do livro como forma de agradecimento/propaganda.

A Global Editora com a anuência da família a cada ano tem publicado novas edições e reedições, ao ponto de colocar em seu catálogo de literatura brasileira a rubrica "Coleção Cora Coralina". Se compararmos as edições anteriormente publicadas pelas editoras goianas, observamos uma mudança significativa no projeto gráfico no intuito de não apenas destacar cenários de Goiás, mas focalizar a imagem da autora. No ano 2000 as capas foram padronizadas, cada obra com uma cor específica, mas com uma linguagem uniforme.Além disso, as reedições trazem fotografias de diferentes fases de vida da autora reforçando a idéia da obra como autobiografia. Uma das orelhas do livro apresenta biografia resumida e na outra é transcrita a primeira carta de Carlos Drummond de Andrade enviada à autora em I4 de julho de 1979 e que constituiu um divisor de águas em sua recepção.A partir de 2005 os livros tiveram seu formato modificado para $16 \times 23 \mathrm{~cm}$, reforma visual que implicou no aumento das letras facilitando a leitura e gerando uma identidade entre os diferentes livros.

A família anunciou que está organizando novas coletâneas de crônicas, poemas e correspondências inéditas. A cada dois anos em média tem se publicado reedições das obras, o que comprova a efetiva circulação do produto. Poemas dos becos, por exemplo, já alcançou a sua vigésima segunda edição. Também é importante observar que não somente nas livrarias é possível adquirir os exemplares. Seguindo a tradição iniciada pela própria autora, o Museu-Casa de Cora 
Coralina constitui em um dos principais pontos de comercialização dos livros. O acervo museológico estimula o interesse pelas obras originadas do acervo documental e vice-versa. Ambos contribuem para a fabricação e propagação da crença no projeto criador de Cora Coralina.

$\mathrm{Na}$ medida em que os herdeiros legais desenvolviam o trabalho de gestão da obra e da imagem, os membros da Associação Casa de Cora Coralina, compostos em sua maioria por amigos e vizinhos da poetisa, definiriam uma organização do acervo documental e do acervo museólogo.A prioridade foi organizar o acervo tridimensional para a primeira exposição do museu inaugurada em 20 de agosto de 1989, dia do centenário de nascimento da poetisa. Conforme destaca Delgado (2005), o Museu-Casa de Cora Coralina configura um projeto de organização e acumulação de diversos tempos da vida da poetisa, um arquivo de objetos, imagens e discursos presentificados que evocam Cora e promovem sua imortalização. Avaliando o primeiro projeto museológico elaborado por Célia Corsino e Virgínia Papaiz, informa que atendeu as expectativas da Associação e, por isso mesmo, a narrativa material da Casa de Cora foi "fruto de uma seleção material e simbólica, cujo interesse não é reproduzir 'tudo como no tempo de Cora', mas enquadrar o passado dentro dos limites da biografia que se quer fabricar e oficializar" (DELGADO, 2005, p. 106). Em outras palavras, a narrativa museológica solidificaria a narrativa autobiográfica produzida pela poetisa e desenvolveria uma lógica análoga a que analisamos nos acervos documentais (até porque aqui os objetos também são tidos como documentos, suportes de significados).Ao montar a exposição, alguns discursos, imagens e objetos são eleitos em detrimento de outros, empenhando-se nas tarefas de produzir lembranças e esquecimentos e de dar a visibilidade simbólica por meio de eventos com o intuito de manter e reinventar o culto a Cora Coralina.

\section{Águas vermelhas}

$\mathrm{Na}$ verdade, as três exposições permanentes que o museu abrigou foram inauguradas em momentos comemorativos. A primeira, como dissemos, foi o ponto alto das comemorações do centenário da poetisa e permaneceu montada de 20 de agosto de 1889 até 31 de dezembro de 200I, data em que uma enchente do Rio Vermelho invadiu o museu. $\mathrm{Na}$ elaboração dessa exposição, as museólogas recorreram ao acervo documental da poetisa apenas para a obtenção de fotografias de diversas fases da autora espalhando-as premeditadamente pela residência e, além de exporem a biblioteca pessoal, colocaram três cadernos de manuscritos e algumas correspondências em vitrines. $O$ rio que embalou a trajetória e a poesia de Cora adentrou a casa poética e política e abraçou manuscritos com poemas, jornais, fotografias, além de objetos pessoais, a estrutura da casa e o jardim do museu. Conforme explicitou Tamaso (2007), essa enchente contribuiu para a visualização do confronto entre os usos plurais da categoria "patrimônio", a partir das tensões entre os artefatos privados e públicos, sagrados e profanos, pessoais e coletivos, evidenciando o sistema de exclusão inerente a lógica da conservação patrimonial. Surge uma revisão da hierarquização das categorias patrimoniais e, enquanto o Museu-Casa de Cora Coralina recebeu atenção, os bens privados, não midiáticos, dos moradores vizinhos (patrimônios pessoais ou familiares), não obtiveram o mesmo espaço na imprensa e nas ações das instituições públicas e privadas.

O fato é que após a enchente os acervos museológico e documental foram restaurados e reorganizados. Devido à importância simbólica e econômica 
que a Casa de Cora conquistou na dinâmica turística da cidade de Goiás, o museu se manteve aberto durante oito meses com uma exposição "improvisada" e os visitantes puderam acompanhar os procedimentos de restauração do imóvel, dos objetos e dos documentos, motivados pelo que poderíamos designar de “consumo do trágico". Com a doação de 150 mil reais, a Telegoiás Brasil Telecom propiciou a restauração do imóvel e do jardim, a renovação da exposição e a separação e o acondicionamento emergencial do acervo. $\mathrm{Na}$ data do aniversário da poetisa, 20 de agosto, a nova expografia foi inaugurada:

Foram instaladas estruturas de vídeo e som pelo museu. Um documentário em DVD, trazendo depoimentos sobre a escritora poderá ser visto durante todo o dia. Aparelhos de TV estarão ligados em determinados pontos da casa, onde serão exibidos vídeos relacionados com a obra da antiga moradora, incluindo declamações da própria Cora. Completando este trabalho, 15 painéis, a maioria com formato $90 \mathrm{X}$ $1,60 \mathrm{~cm}$, foram instalados na residência. Eles contam, em reproduções ampliadas e digitalizadas de documentos e fotografias, a caminhada de Cora pela vida (BORGES, 2002, p. I).

A exposição inaugurada em 2002, sob a curadoria de Célia Corsino, promoveu um diálogo mais explícito com o acervo documental. Conforme destacou a matéria, os painéis espalhados pela casa traziam reproduções ampliadas dos documentos até então inéditos ao grande público. Exposição complementada em 2003 quando o museu destinou uma sala para a exibição do resultado da restauração de alguns manuscritos atingidos pela enchente. Restauração e organização documental de acordo com as normas internacionais de arquivologia subsidiada pela Fundação Vitae. Selecionada dentre mais de mil projetos, a Casa de Cora recebeu 70 mil reais utilizados "na compra dos materiais necessários à restauração, acondicionamento e digitalização dos documentos e treinamento e remuneração de estagiários" (BORGES, 2003, p. 7). Apesar das inovações, o conteúdo dos painéis reforçava a autobiografia escrita pela poetisa. Os documentos dialogavam com trechos de poesias selecionadas para compor ambientes específicos da residência como cozinha, quarto, sala de escrita, sala de condecorações, sala de visitas e biblioteca reiterando determinados marcos biográficos e a idéia de que tudo permanecia como "no tempo de Cora". Questões que ganharam visibilidade no recente projeto de atualização do acervo permanente inaugurado nas comemorações dos 120 anos de nascimento da escritora, em 20 de agosto de 2009. Novamente sob a curadoria de Célia Corsino a exposição foi patrocinada pelo Programa Caixa de Adoção de Entidades Culturais e priorizou a reprodução dos documentos do acervo, inclusive montando uma linha do tempo com os mesmos, e a exibição de fotografias, correspondências e manuscritos de poemas e crônicas, dispostos em doze vitrines ao longo do museu. Para além da ancianidade, a exposição sublinhou aquilo que Delgado (2005, p. I I2) havia identificado como um processo que visava inscrever Cora como arquivo e arauto da memória da cidade, amalgamando a memória da escritora com a Casa Velha da Ponte e, desse modo, transformando a poetisa como um "monumento" de Goiás:"concepção museológica que pretende construir a memória individual como símbolo da memória da cidade, consagrando e imortalizando a Cora-Monumento".

Nesse sentido, a exposição deve ser concebida como um discurso social que visa persuadir o expectador.Aqui dialogamos com o entendimento de Gonçalves (2004) quando analisou a forma como o desenho espacial da exposição e o curador influenciam na recepção estética. Daí porque prefere o termo "ce- 
nografia", pois concebe que na comunicação da exposição ocorre algo próximo do que ocorre no teatro, onde a "cena" apresenta atores desempenhando seus papéis e construindo ficções. Todavia, destaca que na exposição o visitante também pode ser concebido como um ator. Ao percorrer o circuito da mostra se torna um ser ativo que interage com os discursos de acordo com suas experiências. É por isso a necessidade não apenas de trazer o conteúdo de informação, mas desenvolver estratégias para uma melhor apresentação do conteúdo. Daí a busca de novos recursos de comunicação e de envolvimento com seu público, a exemplo dos apresentados pela Casa de Cora Coralina. Desse modo, é fundamental o papel do curador da exposição que "não só faz as obras 'falarem' mas fala sobre elas" (GONÇALVES, 2004, p. I I0). Além disso, ao eleger como curadora a museóloga Célia Maria Corsino, a instituição herda parte do capital simbólico da profissional que, ao mesmo tempo, se legitima ao ser escolhida para encenar uma determinada história a partir de objetos que agem como referências para a memória que se pretende imortalizar.

Todavia, para além desses percursos podemos encerrar nossas análises no gesto metonímico do turista quando leva um livro, um postal com a reprodução de um manuscrito ou qualquer souvenir do Museu-Casa para casa. Como se levasse o acervo e a "intimidade" da autora, o gesto é o mesmo que mobiliza o interesse crescente pela documentação pessoal no mercado de bens simbólicos. A exposição com o acervo literário implica manipular uma memória já manipulada. Porém, para a maioria dos leitores pouco interessa problematizar o que ficou fora da exposição ou do museu, mas consumir tudo o que esteja relacionado ao nome Cora Coralina. Atitude que contribui para fabricar a imortalidade da autora e para alimentar a crença que impulsiona as engrenagens do campo literário.

\section{Referências}

ASSOCIAÇÃO CASA DE CORA CORALINA. Cidade de Goiás-GO. Ata da assembléia de fundação realizada no dia 28 de setembro de 1985. Goiás, 1985.

BORGES, Rogério. Em Goiás, ninguém faz doce igual aos da minha mãe. O Popular, I nov. 2009.

BORGES, Rogério. Acervo de Cora Coralina é recuperado em Goiás. O Popular, 23 nov. 2003.

BORGES, Rogério. Acervo valorizado. O Popular, 17 ago. 2002.

BOURDIEU, Pierre. Razões práticas: sobre a teoria da ação. 8. ed. Campinas, SP: Papirus, 1996a.

BOURDIEU, Pierre. As regras da arte: gênese e estrutura do campo literário. São Paulo: Companhia das Letras, 1996b.

BOURDIEU, Pierre. Questões de sociologia. Rio de Janeiro: Marco Zero, 1983.

BRITTO, Clovis Carvalho; SEDA, Rita Elisa. Cora Coralina: raízes de Aninha.Aparecida, SP: Idéias e Letras, 2009.

CHAGAS, Mário. A poética das casas museus de heróis populares. Revista Mosaico, n. 4, 2008.

CORALINA, Cora.Vintém de cobre: meias confissões de Aninha. 9. ed. São Paulo: Global, 2007.

CORALINA, Cora. Estórias da casa velha da ponte. I3. ed. São Paulo: Global, 2006.

CORALINA, Cora.Vida. In: BORGES, Rogério. O Popular, I 4 mar. 2004.

CORALINA, Cora. Poemas dos becos de Goiás e estórias mais. 20. ed. São Paulo: Global, 200I. 
CUNHA, Eneida Leal. A “Casa Jorge Amado”. In: SOUZA, Eneida Maria de; MIRANDA,Wander Mello (Org.).Arquivos literários. São Paulo:Ateliê Editorial, 2003. DAMATTA, Roberto. Individualidade e liminaridade: considerações sobre os ritos de passagem e a modernidade. Mana, v. 6, n. I, 2000.

DAMATTA, Roberto.A casa e a rua: espaço, cidadania, mulher e morte no Brasil. 5. ed. Rio de Janeiro: Rocco, 1997.

DELEUZE, Gilles; GUATTARI, Félix. Mil platôs: capitalismo e esquizofrenia. Rio de Janeiro: Editora 34, 1995.

DELGADO, Andrea Ferreira. Museu e memória biográfica: um estudo da Casa de Cora Coralina. Sociedade e Cultura, v. 8, n. 2, jul./dez. 2005.

EL FAR,Alessandra.A presença dos ausentes: a tarefa acadêmica de criar e perpetuar vultos literários. Estudos Históricos, 2000.

GONÇALVES, Lisbeth Rebollo. Entre cenografias: o museu a exposição de arte no século XX. São Paulo: Edusp, 2004.

HEYMANN, Luciana Quillet. Cinqüenta anos sem Vargas: reflexões acerca da construção de um “legado”. In: ENCONTRO ANUAL DA ANPOCS, 28., 2004, Caxambu.Anais... Caxambu: [s.n.], 2004.

MOURA, Flávio. Pegada de elefante. Estudos de Sociologia, v. I4, n. 27, 2009.

PEREGRINO, Júlia. Cora Coralina: emoção à flor da letra. In: CORA Coralina: coração do Brasil. São Paulo: Museu da Língua Portuguesa, 2009.

PIRES, Francisco Quinteiro. Cora Coralina, artista apaixonada pela arte de viver. O Estado de São Paulo, 29 set. 2009.

PRATT, Mary Louise. Os olhos do império: relatos de viagem e transculturação. São Paulo: EDUSC, 1999.

PUIG, Renata Guimarães. A arquitetura de Museus-casa em São Paulo (198020I0). 20I I. Dissertação (Mestrado em Interunidades em Estética e História da Arte)- Universidade de São Paulo, $201 \mathrm{I}$.

RAMOS, Anatole. Cora Coralina, o tesouro da casa velha de Vila Boa. O Popular, 17 out. 197I.

RANGEL, Aparecida.Vida e morte no museu-casa. Revista Brasileira de Museus e Museologia, n. 3, 2007.

REZENDE, Joffre. Of. n. ${ }^{\circ}$ 16/8I. Goiânia, 27 de fevereiro de 198।

SENA, André de. Inéditos de Cora Coralina. Correio da Paraíba, jan. 2002.

TAMASO, Izabela. Relíquias e patrimônios que o RioVermelho levou. In: LIMA FILHO, Manuel; BELTRÃO, Jane; ECKERT, Cornélia (Org.). Antropologia e patrimônio cultural: diálogos e desafios contemporâneos. Florianópolis: Nova Letra Editora, 2007. 